\title{
Biotransformation of various carbon sources to kojic acid by cell-bound enzyme system of A. flavus Link 44-1
}

\begin{abstract}
The ability of cell-bound enzyme of Aspergillus flavus Link 44-1 for production of kojic acid was studied in resuspended cell system. Cell material was produced in batch fermentation using $2 \mathrm{~L}$ stirred tank fermenter. The cell mycelia were then resuspended into $250 \mathrm{~mL}$ shake flask containing various carbon sources solution. Among the carbon sources tested, glucose gave the highest kojic acid yield based on carbon consumed $(0.365 \mathrm{~g} / \mathrm{g})$ followed by sucrose $(0.279 \mathrm{~g} / \mathrm{g})$, starch hydrolysate $(0.212 \mathrm{~g} / \mathrm{g})$ and fructose $(0.195 \mathrm{~g} / \mathrm{g})$. The rate of biotransformation was increased with increasing mycelial cell. Kojic acid production was also varied with different glucose and sucrose concentrations. The highest production was obtained at $100 \mathrm{~g} / \mathrm{L}$ glucose and $100 \mathrm{~g} / \mathrm{L}$ sucrose with a final kojic acid concentration of 45.3 and $33.4 \mathrm{~g} / \mathrm{L}$, respectively. The rate of biotransformation of glucose and sucrose to kojic acid followed the Michaelis-Menten equation, suggesting that the biotransformation rate vary with substrate concentration similar to the behaviour of many enzymes reaction.
\end{abstract}

Keyword: Kojic acid, Biotransformation, Cell-bound enzyme, Resuspended cell system, Aspergillus flavus 